\title{
Diagnosis of carpal tunnel syndrome
}

\section{( Diagnostyka zespołu cieni nadgarstka )}

\author{
Jarosław Strychar 1,A,D , Zbigniew Kopański 2,E,F , Gregory Sianos 3,B,C
}

\begin{abstract}
Introduction. Clinical practice indicates that many patients suffering from the carpal tunnel syndrome (CTS) must often go through a long diagnostic path from the onset of the first symptoms of this disease, to making the correct diagnosis and taking the right treatment. Correct diagnosis of CTS is often very difficult to establish.

Aim of the study.The objective of the thesis was to present the most important elements of CTS diagnostics.

Selection of material. The search was carried out in the Scopus database using the concepts of the carpal tunnel syndrome and diagnostics in years 2000-2018. The literature found in the Google Scholar database was analysed in terms of the largest number of citations. Literature selected in this way served as the material for the thesis.

Conclusions. An early diagnosis of CTS and treatment results in the remission of symptoms, thanks to which the patient does not have to give up his professional work and favourite hobby, while comprehensive treatment frequently prevents the consequences of CTS.
\end{abstract}

Key words - carpal tunnel syndrome, diagnostics.

Streszczenie - Wstęp. Praktyka kliniczna wskazuje, że wielu pacjentów cierpiących na zespół kanału nadgarstka (carpal tunnel syndrome - CTS) musi niejednokrotnie przebyć długą drogę diagnostyczną od chwili pojawienia się pierwszych dolegliwości tej choroby, aż do postawienia prawidłowej diagnozy i podjęcia właściwego leczenia. Prawidłowe rozpoznanie CTS jest bowiem niejednokrotnie bardzo trudne do ustalenia.

Cel pracy. Celem pracy było przedstawienie najważniejszych elementów diagnostyki CTS.

Dobór materiału. Poszukiwania przeprowadzono w bazie Scopus używając pojęć zespół kanału nadgarstka, diagnostyka za okres 2000-2018r. Znalezione piśmiennictwo w bazie Google Scholar przeanalizowano pod kątem największej liczby cytowań. Tak wyselekcjonowane piśmiennictwo posłużyło za materiał do opracowania niniejszej pracy.

Wnioski. Możliwie wczesne rozpoznanie CTS i podjęcie leczenia powoduje ustąpienie dolegliwości, dzięki czemu pacjent nie musi rezygnować z wykonywanej pracy zawodowej i ulubionego hobby, natomiast kompleksowe leczenie zapobiega w wielu wypadkach następstwom CTS.

Stowa kluczowe - zespół kanału nadgarstka, diagnostyka.

\author{
Author Affiliations: \\ 1. Collegium Masoviense - College of Health Sciences, Poland \\ 2. Faculty of Health Sciences, Collegium Medicum, Jagiellonian \\ University, Poland \\ 3. Glasgow Royal Infirmary, United Kingdom
}

Authors' contributions to the article:
A. The idea and the planning of the study
B. Gathering and listing data
C. The data analysis and interpretation
D. Writing the article
E. Critical review of the article
F. Final approval of the article

\section{Correspondence to:}

Prof. Zbigniew Kopański MD PhD, Faculty of Health Sciences, Collegium Medicum, Jagiellonian University, Piotra Michałowskiego 12 Str., PL- 31-126 Kraków, Poland, e-mail: zkopanski@o2.pl

Accepted for publication: May 06, 2019.

\section{THE ANATOMY OF MEDIAN NERVE}

$\mathrm{N}^{\mathrm{w}}$ dian nerve comes from the brachial plexus, starts with two roots - medial (C8-Th2) and lateral (C5C7), which connect with each other at the height of the crossing of the lower margin of the pectoralis minor muscle with the axillary artery. On the shoulder, the median nerve runs in the medial furrow of the musculus biceps, initially positioned on the side of the brachial artery. In the distal part, it crosses the front and runs on its medial side, up to the height of cubital fossa. On the forearm, the median nerve is located between the superficial and deep flexor muscles of fingers. In the distal part of the forearm it is located more superficially. On the hand, it passes under the flexor retinaculum through the carpal tunnel. After passing through the carpal tunnel, the median nerve is divided into spinal branches: motor to the muscles of the ball of the 
thumb and sensory to the palmar part of the fingers and to fingers II and III and finally to the radial side of finger IV. The nerve innervates the majority of the muscles of the ball of the thumb (short abductor, antagonist, superficial head of the short flexor) and the I, II and sometimes the third lumbrical muscle. The basic motor function of the median nerve on the hand is to oppose the thumb against other fingers, as well as to abduct and adduct. [1-3]

The aim of the study was to present the most important elements of CTS diagnostics.

\section{SELECTION OF MATERIAL}

The search was carried out in the Scopus database using the concepts of the carpal tunnel syndrome and diagnostics in years 2000-2018. The literature found in the Google Scholar database was analysed in terms of the largest number of citations. Literature selected in this way served as the material for the thesis.

\section{CLINICAL PICTURE OF THE CARPAL TUNNEL SYNDROME}

The first symptoms of the carpal tunnel syndrome (CTS) tend to be brief and not particularly uncomfortable, which is why most patients do not pay attention to them and often ignore them. In the initial stage a patient may experience a feeling of transient numbness or tingling in the area that is supplied by the median nerve. These disorders concern the palmar surface of the finger 1,2,3 and the radial part IV and the dorsal surface of the phalanx III of fingers 1,2,3 ( Figure 1.)
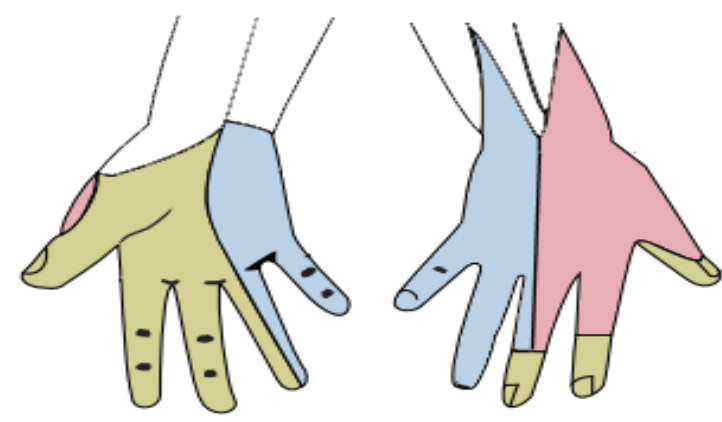

Figure 1. The area of the hand innervated by the median nerve (green) [1]
As the disease progresses, the area increases and the described symptoms, include, apart from the fingers, also the palmar part of the entire hand. The feeling of numbness and tingling can also move radially (proximally) to the forearm, elbow, shoulder and even to the occiput area. [4]

In most cases, the above symptoms are directly related to excessive limb load and disappear almost immediately after the end of physical activity. However, they often come back at night, which causes frequent awakening of the patient. Therefore, they are also called „brachialgia parasthetica nocturna." For some authors, night-time pains are a pathognomonic symptom for this neuropathy of the upper extremity, while for others, the characteristic symptom of CTS is paraesthesia, followed by pain. [5]

Numbness is often accompanied by stiffness and swelling of the upper extremity, which usually occurs after a longer rest, especially during the night. A patient feels relieved when he/she lowers the limb and performs the socalled flick sign, which involves dynamic shaking performed in the same way as when flicking the thermometer. For this reason, flicking of the upper limb is a very characteristic symptom observed in patients with CTS. [6]

In the later phase, persistent pain in the hands may occur, mainly in the night hours, whereas numbness may appear during the day. Typically, this symptom can be observed when performing activities that require the wrist to be put in an uncomfortable position for a long time or when performing activities that require repetitive flexing and straightening movements.

In the course of neuropathy from median nerve compression, sensory disturbances can often occur. In the early phase, they mainly refer to the disturbance of the sensation of vibration, in a more advanced stage of the diseasesuperficial sensory disturbances appear.

Hypaesthesia may also develop, primarily in the area of the fingertips, mainly in the thumb and index finger, with a tendency to spread over the whole area of the sensory nerve supply. [4,5,7]

In many patients, movement disorders, such as paresis and the thenar muscle atrophy, may occur simultaneously from the onset of the disease. They appear most often in the situation when the movement branch of the median nerve (innervating the muscles of the thenar) separates from the nerve trunk inside the carpal tunnel, which can be observed in a significant number of patients with CTS. $[8,9]$

The increase in pressure in the carpal tunnel leading to CTS is usually associated with hypertrophy of the transverse ligament, but it can also result from other causes inducing compression and associated ischaemia of the motor branch of the median nerve. 
These phenomena may also be accompanied by functional disorders of the sympathetic system, which are local in nature and cause the Raynaud's symptom ${ }^{1}$.

The image is complemented by excessive dryness or sweating of the upper limbs, progressive hardening of the fingertips and their cooling. Trophic disorders may also occur in the form of vesicular skin lesions, ulceration on the fingertips and osteolysis.

It is estimated that the above symptoms occur in almost $50 \%$ of patients suffering from CTS. [10-13]

Classification according to the recommendations of Whitley and McDonnell is a frequently used classification for the clinical assessment of CTS. This classification distinguishes three stages of CTS advancement (Table 1).

Table 1. Classification of CTS stages according to Whitley and McDonnell [15]

\begin{tabular}{|c|c|}
\hline $\begin{array}{c}\text { Stages of the } \\
\text { CTS ad- } \\
\text { vancement }\end{array}$ & Characteristics of symptoms \\
\hline I - early (mild) & $\begin{array}{l}\text { the lowest level of CTS advancement. Occasionally, } \\
\text { tingling, numbness and pain in the area innervated by } \\
\text { the median nerve, occur. These symptoms often ap- } \\
\text { pear in a dream and wake a patient who has to "flick" } \\
\text { his hand to restore his/ her normal sensation. }\end{array}$ \\
\hline $\begin{array}{l}\text { II - medium } \\
\text { (moderate) }\end{array}$ & $\begin{array}{l}\text { Patients report symptoms of significant weakening of } \\
\text { sensation, loss of precision in hand movements and } \\
\text { grip strength. The pain experienced is often referred to } \\
\text { as a "burning" one, while its intensity increases fre- } \\
\text { quently at night and during the same operations by } \\
\text { hand. In physical examination one can observe mild or } \\
\text { moderate atrophy and weakening of the ball of the } \\
\text { thumb. }\end{array}$ \\
\hline $\begin{array}{l}\text { III - advanced } \\
\text { stage }\end{array}$ & $\begin{array}{l}\text { III - advanced stage } \\
\text { patients reveal a visible muscle atrophy of the ball of } \\
\text { the thumb, as well as a significant deficit in the preci- } \\
\text { sion of the upper limb. In addition, you can also ob- } \\
\text { serve a loss of the proper two-point sensation and } \\
\text { increased hand function abnormalities }\end{array}$ \\
\hline
\end{tabular}

\section{CTS DIAGNOSTICS}

CTS diagnosis is made on the basis of $4,5,14,16,17]$ :

- medical history,

${ }^{1}$ Raynaud's symptom is a vasomotor disorder characterized by sudden pallor, then bruising and redness of fingers, toes, rarely nose and ear, accompanied by numbness and pain. The disorder may be primary (Raynaud's disease) or secondary, as one of the symptoms of the underlying disease (Raynaud's syndrome).[14]
- physical examination

- examination of the nerve conduction of the median nerve (EMG).

Nowadays, the value of imaging diagnostics - ultrasound and MRI examinations- is also underlined. On the basis of physical examination, it is possible to assess the sensation and function of muscles that are located in the area of median nerve innervation. In CTS diagnostics, this assessment is usually performed with the use of [14,18-20]:

- Semmes-Weinstein monofilaments ${ }^{2}$, which are used to determine the level of feeling of touch ;

- a single-use neurological needle, thanks to which one can determine the level of pain perception

- reed with a frequency of $256 \mathrm{~Hz}$, which allows you to determine the level of vibrations.

In addition, a test that allows you to assess the two-point sensation using a device called a two-point discriminator or compass could be very useful. Considering the twopoint sensory ranges, which can be determined on the basis of the Rosen-Lundborg study ${ }^{3}$, it is assumed that any abnormalities in this range are most common in patients with permanent symptoms, as well as visible muscle wasting in the ball of the thumb (Table 2).[18-20]

Table 2. The ranges of the two-point sensing according to Rosen-Lundborg [15]

\begin{tabular}{|c|c|}
\hline Distance in $\mathrm{mm}$ & Number of points \\
\hline$<=5 \mathrm{~mm}$ & 3 regular result \\
\hline $6 \mathrm{~mm}-10 \mathrm{~mm}$ & 2 points \\
\hline $11 \mathrm{~mm}-15 \mathrm{~mm}$ & 1 point \\
$>=16 \mathrm{~mm}$ & 0 points \\
\hline
\end{tabular}

Physical examination should also include an assessment of the muscular strength of selected muscles of the ball of the thumb, which include the thumb and short thumb abductor based on the Lovett scale and the assessment of the

${ }^{2}$ Semmes and Weinstein's monofilaments are a few centimetres long plastic fibbers, with standardized diameter, stiffness and weight, attached to a handle with a shape and size similar to a pencil. They are used to assess skin sensitivity to touch.[18,19]

${ }^{3}$ The questionnaire was designed by Lundborg and Rosen and published in 2000. It is built from a range of different tests, simple to carry out, and does not require the use of specialized equipment. It consists of three parts: sensory, motor and pain/ discomfort. The "sensory" part consists of the Semmes-Weinstein monofilament testing, the two-point sensory test, the STI (Shape / Texture Identification Test), the shape recognition test and the surface texture test, and the Sollerman test. [18-20] 
maximum hand grip force with the use of a dynamometer. On this occasion, one should also pay attention to muscular atrophy, characteristic for the most advanced forms of CTS. [21]

An extremely important element of CTS diagnostics are provocation tests, which are designed to induce pain and paraesthesia within the median nerve supply. The most common provocative tests used during the physical examination include: Tinel $\operatorname{sign}^{4}$, Phalen $\operatorname{sign}^{5}$ and Phalen and Durkan ${ }^{6}$ inverted signs. [22,23]

Many authors, however, express the opinion that these tests do not have high diagnostic power, therefore they report the need for further, systematic and detailed clinical tests in this area.

The EMG and USG are one of the standard diagnostic tests performed on persons suffering from CTS. Using the EMG test, one can evaluate the conductivity in the median nerve and thus assess the slowdown of the conductivity speed (3ms) and the motor potentials extension ( $>4 \mathrm{~m} / \mathrm{s}$ ) as well as the decrease in potential amplitudes $(<20 \mathrm{uV})$ (Table 3).[19,24]

Table 3. Classification of CTS severity based on EMG [25]

\begin{tabular}{|c|c|c|c|}
\hline & Mild & Moderate & Advanced \\
\hline Movement latency & $\begin{array}{c}4,0-5,0 \\
\mathrm{msec}\end{array}$ & $5,0-7,0 \mathrm{msec}$ & $\begin{array}{c}>7,0 \mathrm{msec} \text { or } \\
\text { negative }\end{array}$ \\
\hline $\begin{array}{c}\text { Sensory latency } \\
\begin{array}{c}3,0-4,-0 \\
\mathrm{msec}\end{array}\end{array}$ & $4,0-6,0 \mathrm{msec}$ & $\begin{array}{c}>6,0 \mathrm{msec} \text { or } \\
\text { negative }\end{array}$ \\
\hline $\begin{array}{c}\text { Amplitude of sens- } \\
\text { es }\end{array}$ & $\begin{array}{c}\text { under } \\
20 \mathrm{uV}\end{array}$ & under 20uV & $\begin{array}{c}\text { under 20uV } \\
\text { or negative }\end{array}$ \\
\hline Denervation & negative & negative & positive \\
\hline
\end{tabular}

Ultrasound examination is now treated as a standard in CTS diagnostics, which results mainly from its availability, non-invasiveness and short time necessary to perform this test at relatively low costs. Thanks to the examination, one can observe the features of the median nerve pressure in

\footnotetext{
${ }^{4}$ Tinel sign- involves tapping the trunk of the examined peripheral nerve. The nerve lacking the myelin sheath gives a numbness reaction when tapped.[16,21]

${ }^{5}$ Phalen sign: You should lift the hand forward and bend at the elbow so that a right angle is created. Then you should bend the wrist as much as possible. The fingers and hand should be relaxed. You should keep this position for one minute. At the carpal tunnel syndrome, there usually appears numbness, tingling or a feeling of nerve current along the nerve.[22]

${ }^{6}$ Inverted Phalen sign: it is performed with joined hands, as if in prayer, with straightened fingers, and elbows drawn to the side so that the wrists are maximally bent and the fingers pressed against each other. The symptom is positive when there is a tingling sensation that radiates towards the arm. [16,22]
}

the carpal tunnel, in terms of its location and cause. Based on the results of the ultrasound examination which related to the cross-sectional area (CSA) of the median nerve, the CTS severity scale was also developed. On this basis, it was assumed that in a healthy person the above mentioned area of the median nerve cross section will oscillate in the range between $0.07-0.1 \mathrm{~cm} 2$, while the value exceeding $0.1 \mathrm{~cm} 2$ would indicate the appearance of CTS. Median nerve oedema revealed on the basis of an ultrasound examination already in the initial stage of the disease may allow to determine the correct diagnosis (Table 4). [26-29]

Table 4. Classification of CTS severity based on wrist ultrasound examination [30]

\begin{tabular}{|c|c|}
\hline Level & $\begin{array}{c}\text { Cross section of the median } \\
\text { nerve }\end{array}$ \\
\hline Low & $10-12,9 \mathrm{~mm}$ \\
\hline Medium & $13-14,9 \mathrm{~mm}$ \\
\hline Severe & $\geq 15 \mathrm{~mm}$ \\
\hline
\end{tabular}

\section{CTS AND THE QUALITY OF PATIENT'S LIFE}

Clinical practice shows that many patients suffering from CTS often have to go through a long diagnostic path from the onset of the first symptoms of this disease to the correct diagnosis and the right treatment. Correct diagnosis of CTS is often very difficult to determine. In general, the greatest diagnostic difficulties occur in the initial stage of the disease. A possible early diagnosis of CTS and the right treatment results in the remission of symptoms, thanks to which the patient does not have to give up his professional work or favourite hobby, while comprehensive treatment frequently prevents the consequences of CTS. [31-33]

As a rule, CTS significantly reduces the quality of life of patients, limiting the performance of basic daily activities, which is why proper, fast diagnostics and proper treatment of this syndrome become so important.

\section{REFERENCES}

[1]Loukas M, Louis RG Jr, Stewart L, Hallner B, DeLuca T, Morgan W, Shah R, Mlejnek J. The surgical anatomy of ulnar and median nerve communications in the palmar surface of the hand. J Neurosurg 2007 May;106(5):887-93.

[2] Kozin SH. The anatomy of the recurrent branch of the median nerve. J Hand Surg 1998 Sep;23(5):852-8. 
[3]Eskandari MM et al. Topographic localization of the motor branch of the median nerve. J Hand Surg 2005; 30A,4: 803-807.

[4]Aroori S, Spence RA: Carpal tunnel syndrome. Ulster Med J 2008; 77 : 6-17.

[5]Nora DB, Becker J, Ehlers JA, Gomes I. What symptoms are truly caused by median nerve com-pression in carpal tunnel syndrome? Clin Neurophysiol 2005; 116: 275-283.

[6]Borisch N, Haussmann P. Neurophysiological recovery after open carpal tunnel decompression: comparison of simple decompression and decompression with epineurotomy. J Hand Surg 2003; 28B: 5: 450-454.

[7]Kmieciak $Ł$, Krokera K. Etiologia i patofizjologia uszkodzenia nerwu pośrodkowego w zespole cieśni nadgarstka. Kwart Ortop 2007; 66:128-137.

[8]Nakasato YR. Carpal tunnel syndrome in the elderly. J Okla State Med Assoc 2003;1: 96-113.

[9] Nowak M, Jethon J. Zespół cieśni nadgarstka-przegląd literatury i doświadczenia własne. Post Nauk Med 2009;9:665-672.

[10] Palmer KT, Harris EC, Coggon D. Carpal tunnel syndrome and its relation to occupation: a systematic literature review. Occup Med 2007; 57: 57-66

[11] Ibrahim I, Khan WS, Goddard N, Smitham P. Carpal tunnel syndrome: a review of the recent literature. Open Orthop J 2012; 6:6976.

[12] Dawson DM, Hallett M, Wilbourn AJ. Entrapment neuropathies. Philadelphia; Lippincott-Raven Publishers, 2009.

[13] Banach M, Bogucki A. Zespoły z ucisku: diagnostyka i leczenie. Kraków; Medycyna Praktyczna, 2003.

[14] Grabb and Smith's Plastic Surgery. London; Lippincott Williams \& Wilkins, 2017.

[15] Mumenthaler M, Schliack H. Uszkodzenia nerwów obwodowych rozpoznanie i leczenie. Warszawa; Wydawnictwo PZWL, 1998.

[16] El Miedany Y, Ashour S, Youssef S, Mehanna A, Meky FA. Clinical diagnosis of carpal tunnel syndrome: old tests-new concepts. Joint Bone Spine 2008; 75: 451-457.

[17] Nawrot P, Nowakowski A, Bartochowski Ł. Współczesne poglądy dotyczące diagnostyki i leczenia zespołu kanału nadgarstka. Chir Narz Ruchu 2008; 73: 112-115.

[18] Sadeh M, Gilad R, Dabby R, Blumen SC. Apparent weakness of ulnar-innervated muscles in radial palsy. Neurology 2004; 62: 14241425.

[19] Rosen B, Lundborg G. A model instrument for the documentation of outcome after nerve repair. J Hand Surg 2000; 25A: 3: 535-543

[20] Rosen B, Lundborg G. A new model instrument for outcome after nerve repair. Hand Clin 2003; 19: 463-470.

[21] Bożek M, Gaździk TS. Wartość badania klinicznego w diagnostyce zespołu kanału nadgarstka. Ortop Traumatol Rehab 2001; 3(3): 357360.

[22] Georgiew F, Otfinowska E, Adamczyk T: Testy diagnostyczne stosowane w rozpoznawaniu zespołu kanału nadgarstka. Rehabil Med 2008; $12: 24-35$.

[23] Massy-Westropp N, Grimmer K, Bain G. A systematic review of the clinical diagnostic tests for carpal tunnel syndrome. J Hand Surg (Am.) 2000; 25: 120-127.

[24] Park GY, Kim SK, Park JH. Median nerve injury after carpal tunnel injection serially followed by ultrasonographic, sonoelastographic, and electrodiagnostic studies. Am J Phys Med Rehab 2011 Apr; 90(4):336-41.

[25] Blumenthal S, Herskovitz S, Verghese J. Carpal tunnel syndrome in older adults. Muscle Nerve 2006,2:78-83.

[26] Domanasiewicz A, Koszewicz M, Jabłecki J. Porównanie wartości diagnostycznej badań ultrasonograficznego i neurograficznego w zespole cieśni nadgarstka. Neurol Neuroch Pol 2009; 43:433-438
[27] Bagatur AE, Zorer G, Oral B. The role magnetic resonance imaging in carpal tunnel syndrome. Correlation of clinical, electrodiagnostic and intraoperative findings staging. Acta Orthop Traumato 2002; 36, 22-27.

[28] Miller K, Kłopotowski J, Bazylewicz A. Zasady orzekania o etiologii zawodowej zespołu cieśni nadgarstka i zespołu rowka nerwu łokciowego. [W:] Zespoły z ucisku diagnostyka i leczenie. Banach M, Bogucki A. (red.). Kraków; Medycyna Praktyczna 2003: 83-89.

[29] Kapuścińska K, Urbanik A. Ultrasonograficzna ocena nerwu pośrodkowego w zespole kanału nadgarstka. Prz Lek 2013; 70: 335338 .

[30] Żyluk A, P. Puchalski, P. Nawrot, Przydatność badania USG w diagnostyce zespołu kanału nadgarstka - przegląd piśmiennictwa. Chir Narz Ruchu 2010;2: 385-391.

[31] Dincer U, et al. The effectiveness of conservative treatments of carpal tunnel syndrome: splinting, ultrasound and low level laser therapies. Photomed Laser Surg 2009; 27, 1: 119-125.

[32] Mathes SJ, Hentz VR. Plastic Surgery. Philidelphia; Saunders Elsevier, 2012.

[33] Viera AJ. Management of carpal tunnel syndrome. Am Fam Physician 2003; 68: 265-272. 